Role of agricultural engineering in environmental and sustainable development

for the valley and delta areas: 1365 - 1380

\title{
CHARACTERISTICS IMPROVEMENT OF BUILDING MATERIALS FABRICATED FROM AGRICULTURAL RESIDUES
}

\author{
KHAIRY ${ }^{1}$, M.F.A; MOSALLAM², M.A. and \\ EL-BESSOUMY ${ }^{3}$, R.R.
}

\begin{abstract}
For improving the qualities of the straw brick (as control), three waste materials and sand were used to replace partially the straw. The waste materials are rubber, glass and mix of rubber and glass. The replacement ratios were 15, 30 and $45 \%$ by weight basis. After carrying out the replacements, the bricks were tested for each of the following characteristic: bulk density, water absorption percentage, compressive stress, thermal conductivity and acoustical insulation percentage. Generally the resulted bricks were superior for the previously mentioned characteristics than the control brick. Replacing sand into the straw brick (control) resulted in less water absorption; less thermal conductivity and more acoustical insulation percentage while replacing a mix of glass and rubber resulted in more compressive stress in comparison with the control brick.
\end{abstract}

\section{INTRODUCTION}

evolution in the agricultural sector has resulted in substantial
increases in the quantities of agricultural by-products and wastes
of different types. Most of these wastes are not adequately managed and utilized. Accumulating of unmanaged wastes especially in developing countries has resulted in an increasing environmental concern. They are mostly disposed of by incineration or used as fuel, although their calorific value is much lower than that of coal. Little work has been carried out to develop utilization of these wastes in the production of building materials.

\footnotetext{
* Research taken from PhD thesis, Dept. of Ag. Eng., Fac. of Ag. (Cairo), Al-Azhar U.

(1) Prof. Of Ag. Eng. Dept. of Ag. Eng., Fac. of Ag. (Cairo), Al-Azhar U.

(2) Ass. Prof. Of Ag. Eng. Dept. of Ag. Eng., Fac. of Ag. (Cairo), Al-Azhar U.

(3) Ass. Lect. Of Ag. Eng. Dept. of Ag. Eng., Fac. of Ag. (Cairo), Al-Azhar U. (PhD's Author).
} 
Since a large demand has been placed on building material industry especially in the last decade owing to the increasing population that causes a chronic shortage of building materials, the civil engineers have been challenged to convert the industrial wastes to useful building and construction materials.

One of the most abandoned materials in Egypt is cellulous non-wood fibrous materials, such as rice straw. The total annual Egyptian crop residues are about $30 \mathrm{Tg}$, about $3 \mathrm{Tg}$ of which is rice straw (FAO,2005). In fact, rice straw is so abandoned that the Egyptian government allowed straw burning at agricultural fields. In the fall of 1999, an autumnal black cloud appeared above several Egyptian cities, with a thick bitter-smelling fog, due to the straw burning. Consequently, instead of burning the straw, recycling it with a mixture of cement forms a sustainable low-cost building material, which also reduces atmospheric pollution (Kazragis, 2005). In addition to these benefits, the straw could act as a thermal insulation material for the unpleasant Egyptian weather. The use of thermal insulation helps reduce energy costs, while creating pleasant indoor temperatures. Egypt is probably one of the first countries in the world to use straw as a building material. By 4000 B.C., Egyptians used sun dried bricks mad out of clay and straw in building entire villages. Even today, clay with straw is used as building housing material in Egyptian rural areas (Mansour et al., 2007). Mixing cement with one or more of the agricultural residues for brick making is a promising role in utilizing crop residues with some modification of the brick characteristics. The concept is new and not many research publications could be found in the literature. There are drawbacks for building materials which fabricated from agricultural residues as increasing water absorption percentage, insects (as pests, termites, and mice) and decreasing compression stress. Therefore, the main aim of this research is to investigate possibility of improving some of building materials characteristics which fabricated from agricultural residues. Staniforth (1979), Alaa El-Din et al. (1983) and Suliman and ElZahaby (1998) mentioned that the crops residues are materials that remain after the edible grain, seed, fruit, or primary fibers has been removed from plant. Hermansson (1993) said that the mix of 30\% straw 
and $70 \%$ cement was put into $400 \times 400 \times 100 \mathrm{~mm}$ (16" x16"x4") molds and compressed by a load of $5 \mathrm{kN} / \mathrm{m}^{2}$. The slabs were stripped after 48 hours and put in a kiln at $50^{\circ} \mathrm{C}\left(122^{\circ} \mathrm{F}\right)$ for additional 48 hours. In the last step, the blocks were put in a basket tunnel to dry. Mansour et al. (2007) said that the final list materials needed for the unit blocks production is: straw, Portland cement, water, and a chemical solution for neutralization, acceleration, and adhesion of the straw with the cement. Cement-straw sample block units have been prepared to demonstrate the production methodology. The treated and dried straw should be mixed with cement in several steps. The first step was preparation of slurry, which was a liquid mixture of water, cement and accelerating material, with ratio of 1:2:0.1 respectively. After preparation of slurry, the treated and dried straw had to be added with straw-cement ratio of 1:3. Finally, the straw and cement should be mixed well to obtain a homogenous material. Turgut (2008) said that the compressive strengths of the masonry blocks containing $25 \%, 50 \%$, and $75 \%$ waste glass powder (WGP) of cement weight were $6.2 \%, 11.6 \%$ and $21.1 \%$ higher than that of the control masonry block, respectively. Flexural strength of the masonry blocks containing $25 \%, 50 \%$, and $75 \%$ WGP of cement weight were $18.6 \%$, $41.2 \%$ and $77.3 \%$ higher than that of the control masonry block, respectively. Shayan (2004) added that the glass powder in concrete improved some durability properties of concrete. Corinaldesi et al. (2005) said that no reaction is detected with particle glass size up to 100 $\mu \mathrm{m}$ indicating the feasibility of the waste glass reuse as fine aggregate in mortars and concrete. Yang et al.(2004) investigated that the possibility of using waste tires and rice straws as composite materials, and the potential applications for which these material could be used after recycling. Waste tires have hardness and elasticity properties superior to those of rubber, good resistance to weathering, can be used for preventing impact damage, and for construction materials, because of their low specific gravity which is lower than that of most construction materials. Moreover, it is possible to use tires in almost any environmental conditions and in any climate, due to their ability to withstand both hot and cold, and their anti-caustic and anti-rot properties They added that the rice straw-waste tire particle composite boards had better flexural 
properties than wood particleboard, insulation board, fiberboard, plywood and various other construction materials. The sound absorption coefficients of the composite boards were higher, in the middle and high frequency range, than those of commercial wood-based materials Sukontasukkul (2009) mentioned that the crumb rubber from used tires, produced in a local recycling plant, was used to replace fine aggregate at ratios of $10 \%, 20 \%$ and $30 \%$. The mix proportion for the control specimen (no crumb rubber) was set at 1.00:0.47:1.64:1.55 (cement: water: fine aggregate: coarse aggregate). The strength of concrete mixed with crumb rubber is quite low (as compared to plain concrete) and tend to decrease with increasing rubber content. The test result showed that, the bulk density of concrete mixed with crumb rubber was found to decrease gradually with the rubber content compared to normal concrete. By replacing conventional fine aggregate with crumb rubber at $10-30 \%$, the unit-weight of concrete can be reduced from $14 \%$ up to $28 \%$ depending on the type and the content of the crumb rubber. The replacing rate of $10 \%$, both compressive and flexural strengths were found to decrease by $35 \%$ and $28 \%$, respectively. At $20 \%$, the strength of crumb rubber was decreased to only about $22-28 \%$ of that of plain concrete. The CR concrete exhibits superior thermal and sound properties than plain concrete as measured by the decrease in thermal conductivity coefficient (k) and the increase in sound absorption coefficient $(\alpha)$ and noise reduction coefficient (NRC).

\section{MATERIALS AND METHODS}

As a reference, a straw brick (control) was formed from cement, water and straw at ratios, 1.4: 0.7: 0.6 by weight respectively. Cement used in this study is Egyptian Portland cement. Tape water was used. The straw used in this study was rice straw. The used straw screened through a sieve of $2 \mathrm{~mm}$ diameter. The ground glass used in this study, recycled from the glass waste. The grinding process achieved manually to get the required quantity. The ground glass screened by using a sieve to the desired size. The ground glass size was about $\leq 2 \mathrm{~mm}$. The used crumb rubber was obtained by grinding recycled vehicle tires into small particles. Rubber pieces were fed into the cutting wheel of the grinding machine repeatedly until the desired size had been achieved. The size of 
the crumb rubber obtained is about $1 \mathrm{~mm}$. The used fine sand was obtained by screened by using sieve of $2 \mathrm{~mm}$. The used sand screened by using a sieve to the desired size. The used fine sand size was about $\leq 2$ $\mathrm{mm}$. The mold used in forming the experimental samples is mad of mild steel and is of dimensions $25 \times 12 \times 10 \mathrm{~cm}$ and thickness of $0.7 \mathrm{~cm}$. The hydraulic press used in manufacturing sample is of maximum pressing load of 260 bar made by SICMI sa.s., Trecasali (Parma), Italy. A digital sound level meter used to measure acoustical insulation percentage is of range $50 \mathrm{~dB}$ to $126 \mathrm{~dB}$ mad by China. The compartment inside which the samples is put for testing acoustical insulation percentage is mad of foam with dimensions of $680 \times 350 \times 350 \mathrm{~mm}$. the thermal conductivity used in this study is manufactured according to Lee's method (Noakes et al., 1953). Thirteen different types (control and three ratios of replacement of each of rubber, glass, mix and sand) of mixtures are prepared in the laboratory. All types of mixtures are prepared for producing bricks samples. (GRS), the abbreviation refers to the first letters of the statement: Ground Rubber Straw. The abbreviation refers to the used materials and its condition. The control mixture contains water, cement and ground rice straw (GRS) with ratio of 0.7:1.4:0.6 respectively. The water and cement proportion in all mixtures are taken as constant to determine the effect of various ground glass waste (GGW), ground rubber waste (GRW), sand, both of (GGW) \& (GRW) and (GRS) combinations. The replacement ratios between each of GGW, GRS, both of GGW \& GRW, sand and GRS are taken in weight basis. The following measurements were made at each brick sample after about 4 weeks: 1bulk density 2- water absorption 3-compressive stress 4- thermal conductivity 5- acoustical insulation 6- expansion ratio. Before measuring brick Samples, the moisture content "MC" is determine for all types of mixture. For each type of the thirteen different types, eight replicates were manufactured. Testing the manufactured samples was carried after four weeks from the time of press. The sequence and number of replicates used for each type for testing was as follows: firstly the bulk density was determined for the eight replicates of each type. Then for three of the eight replicates, water absorption percentage was carried out. This test consumed the three replicates out of the five remaining 
replicates; three replicates were tested for acoustical insulation percentage. The same replicates used for acoustic test were consumed under thermal conductivity test. Out of the 2 remaining replicates, one replicate was cut into three pieces and these three pieces were used for thermal conductivity test. The remaining replicate was consider as a stock

\section{RESULTS AND DISCUSSION}

\section{Effect of the replaced materials:}

For the purpose of investigating the effect of replacing each of the materials; rubber, glass, mix of rubber and glass, under range of replacement of $15-45 \%$ on the tested characteristics compared to the control straw brick, the mean value for the three ratios for each matter was estimated and compared to the correspond value of the control. Table (1) shows the mean values of bulk density $\left(\mathrm{g} / \mathrm{cm}^{3}\right)$ for different mixtures. The maximum mean value of bulk density was $1.14 \mathrm{~g} / \mathrm{cm}^{3}$ for CSS, the abbreviation refers to the first letters of the statement: Cement, Straw and Sand. The abbreviation refers to the produced brick by replacing Sand into the control brick. The minimum mean value of bulk density before pressing was $0.84 \mathrm{~g} / \mathrm{cm}^{3}$ for CS, the abbreviation refers to the first letters of the statement: Cement and straw. The abbreviation refers to the produced control brick. Table (2) shows the mean values of compression stress $\left(\mathrm{N} / \mathrm{cm}^{2}\right)$ for different mixtures. The maximum mean value of compression stress was $419.18 \mathrm{~N} / \mathrm{cm}^{2}$ for CSM (Cement, Straw and mix of glass and rubber) mixtures.

Table (1): The mean values of bulk density $\left(\mathrm{g} / \mathrm{cm}^{3}\right)$ for different mixture

\begin{tabular}{|c|c|}
\hline Type of mixture & $\begin{array}{c}\text { Bulk density } \\
\left(\mathbf{g} / \mathbf{c m}^{\mathbf{3}}\right)\end{array}$ \\
\hline CS & 0.84 \\
\hline CSG & 1.03 \\
\hline CSR & 0.92 \\
\hline CSS & 1.14 \\
\hline CSM & 1.10 \\
\hline
\end{tabular}


Table (2): The mean values of compression stress $\left(\mathrm{N} / \mathrm{cm}^{2}\right)$ for different mixtures.

\begin{tabular}{|c|c|}
\hline $\begin{array}{c}\text { Type of } \\
\text { mixture }\end{array}$ & $\begin{array}{c}\text { Compressi } \\
\text { on stress } \\
\text { "尔 } \\
\left(\mathbf{N} / \mathbf{c m}^{2}\right)\end{array}$ \\
\hline CS & 125.81 \\
\hline CSG & 271.28 \\
\hline CSR & 96.31 \\
\hline CSS & 302.59 \\
\hline CSM & 419.18 \\
\hline
\end{tabular}

The minimum mean value of compression stress was $96.31 \mathrm{~N} / \mathrm{cm}^{2}$ for CSR (Cement, Straw and Rubber) mixture. Table (3) shows the mean values of thermal conductivity "K" (w/m.c. $\mathrm{c}^{\circ}$ ) for different mixtures. The obtained data indicated that the maximum mean value of thermal conductivity "K" was $0.0455 \mathrm{w} / \mathrm{m} . \mathrm{c}^{\circ}$ for CSR mixture. The minimum mean value of thermal conductivity "K" was $0.0217 \mathrm{w} / \mathrm{m} . \mathrm{c}^{\circ}$ for CSS mixture.

Table (3): The mean values of thermal conductivity "K" $\left(\mathrm{w} / \mathrm{m} . \mathrm{c}^{\circ}\right)$ for different mixtures.

\begin{tabular}{|c|c|}
\hline & \\
\hline CS & \\
\hline CSG & 0.0349 \\
\hline CSR & 0.0455 \\
\hline CSS & 0.0217 \\
\hline & 0.0318 \\
\hline
\end{tabular}


Table (4) shows the mean values of acoustical insulation percentage

(\%) for different mixtures. The obtained data indicated that the maximum mean value of acoustical insulation percentage (\%) was $15.53 \%$ for CS mixture. The minimum mean value of acoustical insulation percentage (\%) was $9.09 \%$ for CSR mixture.

Table (4): The mean values of acoustical insulation percentage (\%) for different mixtures.

\begin{tabular}{|c|c|}
\hline 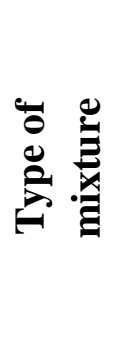 & 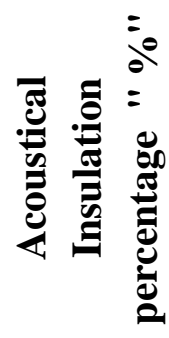 \\
\hline $\mathrm{CS}$ & 15.53 \\
\hline $\mathrm{CSG}$ & 10.61 \\
\hline CSR & 9.09 \\
\hline CSS & 13.64 \\
\hline CSM & 12.88 \\
\hline
\end{tabular}

Table (5) shows the mean values of water absorption percentage (\%) for different mixtures. The obtained data indicated that the maximum mean value of water absorption percentage (\%) was $111.3 \%$ for CS mixture. The minimum mean value of water absorption percentage (\%) was 66.58 $\%$ for CSS mixture.

Table (5): The mean values of water absorption percentage (\%) for different mixtures.

\begin{tabular}{|c|c|}
\hline Type of mixture & $\begin{array}{l}\text { Water Absorption } \\
\text { percentage " \%" }\end{array}$ \\
\hline CS & 111.30 \\
\hline CSG & 75.17 \\
\hline CSR & 81.96 \\
\hline CSS & 66.58 \\
\hline CSM & 71.86 \\
\hline
\end{tabular}




\section{Effect of the ratios of each replaced materials:}

Fig.(1) shows the relationship between bulk density "B.d" and replacement ratio (\%) by weight basis for CS, CSG, CSR, CSS, and CSM mixtures. The obtained data indicated that the bulk density increases with the increasing of replacement ratio (\%). These results were expected because of the replacement ration effect. The maximum value of bulk density was $1.26 \mathrm{~g} / \mathrm{cm}^{3}$ for CSS mixture at $45 \%$ replacement ratio. The minimum value of bulk density under pressing was $0.84 \mathrm{~g} / \mathrm{cm}^{3}$ for CS mixture. From the graph it is obvious that bulk density increases as replacement ratios increases. Generally the lower bulk density obtained is for GRW while the higher bulk density for sand. Fig.(2) shows the relationship between compression stress $\left(\mathrm{N} / \mathrm{cm}^{2}\right)$ and replacement ratio (\%) by weight basis for CS, CSG, CSR, CSS, and CSM mixtures. The obtained data indicated that generally the compression stress $\left(\mathrm{N} / \mathrm{cm}^{2}\right)$ increases for CSM, CSS, CSG and CSR respectively. At any replacement ratio, CSR mixture had lower values than the other mixtures. From 0-15 \% replacement ratio, the compression stress is increasing for CSG, CSR, CSS, and CSM mixtures.

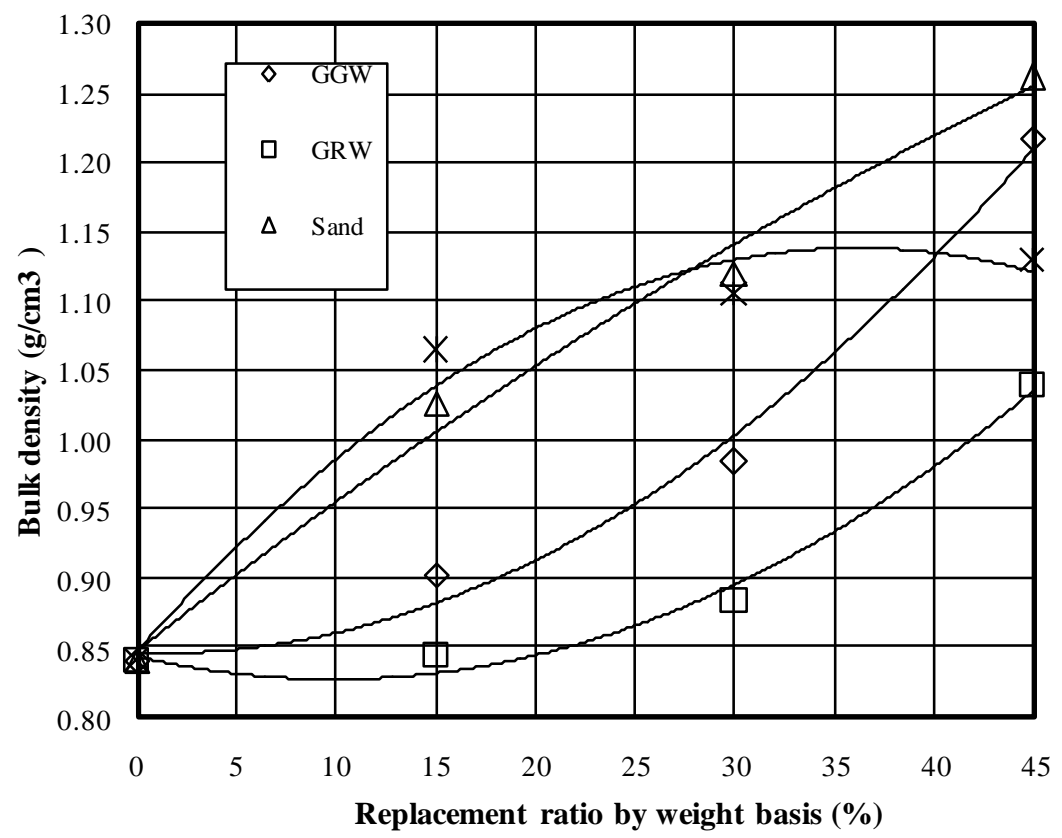

Fig.(1): Relationship between bulk density and the replacement ratios by weight basis for the four tested materials. 
The maximum value was $520.86 \mathrm{~N} / \mathrm{cm}^{2}$ for CSM mixture at replacement ratio of $15 \%$, the minimum value was $152.93 \mathrm{~N} / \mathrm{cm}^{2}$ for CSR mixture at replacement ratio of $15 \%$. From $15-30 \%$ replacement ratio, the compression stress is increasing for CSS and CSG mixtures respectively. The maximum value was $320.92 \mathrm{~N} / \mathrm{cm}^{2}$ for CSS mixture at replacement ratio of $30 \%$, the minimum value was $235.25 \mathrm{~N} / \mathrm{cm}^{2}$ for CSG mixture at replacement ratio of $30 \%$. The compression stress is decreasing by increasing the replacement ratio $\%$ from $15-30 \%$. The compression stress had the higher values for CSM, CSS and CSG mixtures respectively until replacement ration of about $41.5 \%$ the reverse is happed. The compression stress is increasing by increasing rate for CSG mixture and increasing by decreasing rate for CSS mixture. From these results the mixture CSM which contains mix of both GGW and GRW better than the mixture contains only each one and the mixture contains the sand. The mixture CSS contains sand is better than the mixture contain GGW and the mixture contains the GRW. Fig. (3) Illustrates the relationship between thermal conductivity "K" (w/m.c $\left.\mathrm{c}^{\circ}\right)$ and replacement ratio (\%) by weight basis for CS, CSG, CSR, CSS, and CSM mixtures.

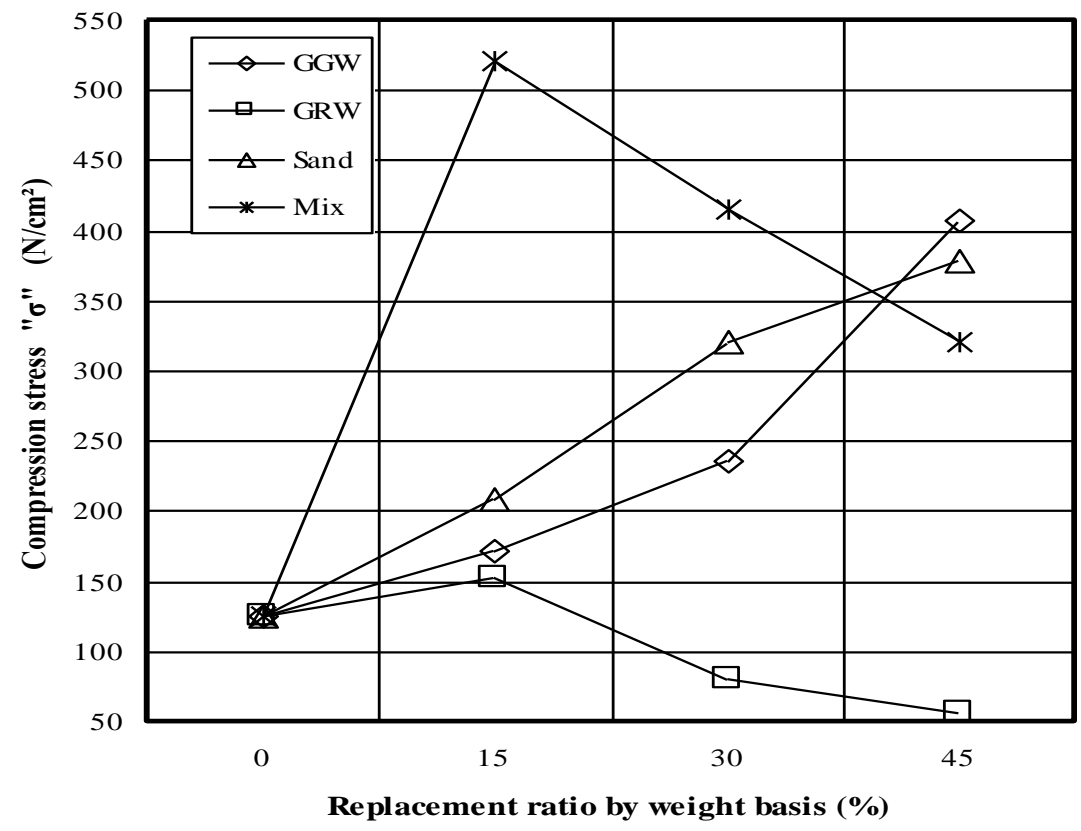

Fig.(2): Relationship between compressive stress and the replacement ratios by weight basis for the four tested materials. 
The obtained data indicated that generally the thermal conductivity " $\mathrm{K}$ $\left(\mathrm{w} / \mathrm{m} . \mathrm{c}^{\circ}\right.$ ) increases with increasing replacement ratio (from $15 \%$ ) for CSR, CSG, CSM and CSS respectively, the maximum value of thermal conductivity "K was $0.0621 \mathrm{w} / \mathrm{m} . \mathrm{c}^{\circ}$ for CSM mixture at $45 \%$ replacement ratio. The minimum value of thermal conductivity was $0.0115 \mathrm{w} / \mathrm{m} . \mathrm{c}^{\circ}$ for CSM mixture at $15 \%$ replacement ratio.

The thermal conductivity "K (w/m.c $\left.\mathrm{c}^{\circ}\right)$ decreased from $0-15 \%$ replacement ratio for CSR, CSG, CSS and CSM respectively. From replacement ratio of $22.5-45 \%$, CSS mixture had lower values than the other mixtures and this is mean that the sand better in thermal insulation than the other, from 15-22.5\% replacement ratio the CSM had the lower values in thermal conductivity "K $\left(\mathrm{w} / \mathrm{m} \cdot \mathrm{c}^{\circ}\right)$ and this is mean that the mix of GGW and GRW is better than the sand in this range. From $22.5-45 \%$ replacement ratio, the increasing rate for CSS mixture is lower than the increasing rate for the CSM mixture and this mean that the sand is better than mix of GGW\&GRW in thermal insulation at this range too.

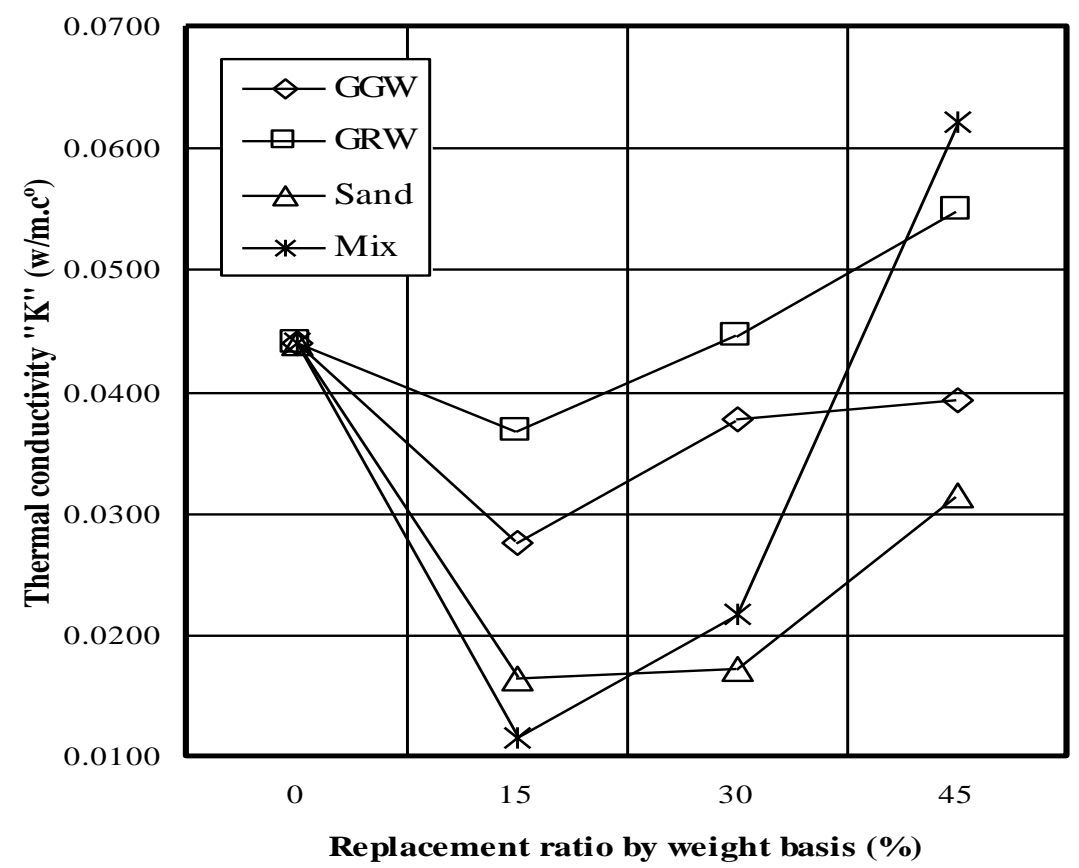

Fig.(3): Relationship between thermal conductivity and the replacement ratios by weight basis for the four tested materials. 
The CSG mixture had lower values in thermal conductivity than CSR and this mean that the GGW better than GRW in thermal insulation, the thermal conductivity is increasing by decreasing rate for CSG mixture while the thermal conductivity is increasing by increasing rate for CSR mixture.

Fig. (4) Shows that the relationship between acoustical insulation percentage (\%) and replacement ratio (\%) by weight basis for CS, CSG, CSR, CSS, and CSM mixtures.

The obtained data indicated that generally the acoustical insulation percentage (\%) decreases with increasing replacement ratio for CSR, CSG, CSM and CSS respectively, the maximum value of acoustical insulation percentage (\%) was $15.53 \%$ for CS (control) mixture. The minimum value of acoustical insulation percentage (\%) was $8.33 \%$ for CSR mixture at $45 \%$ replacement ratio.

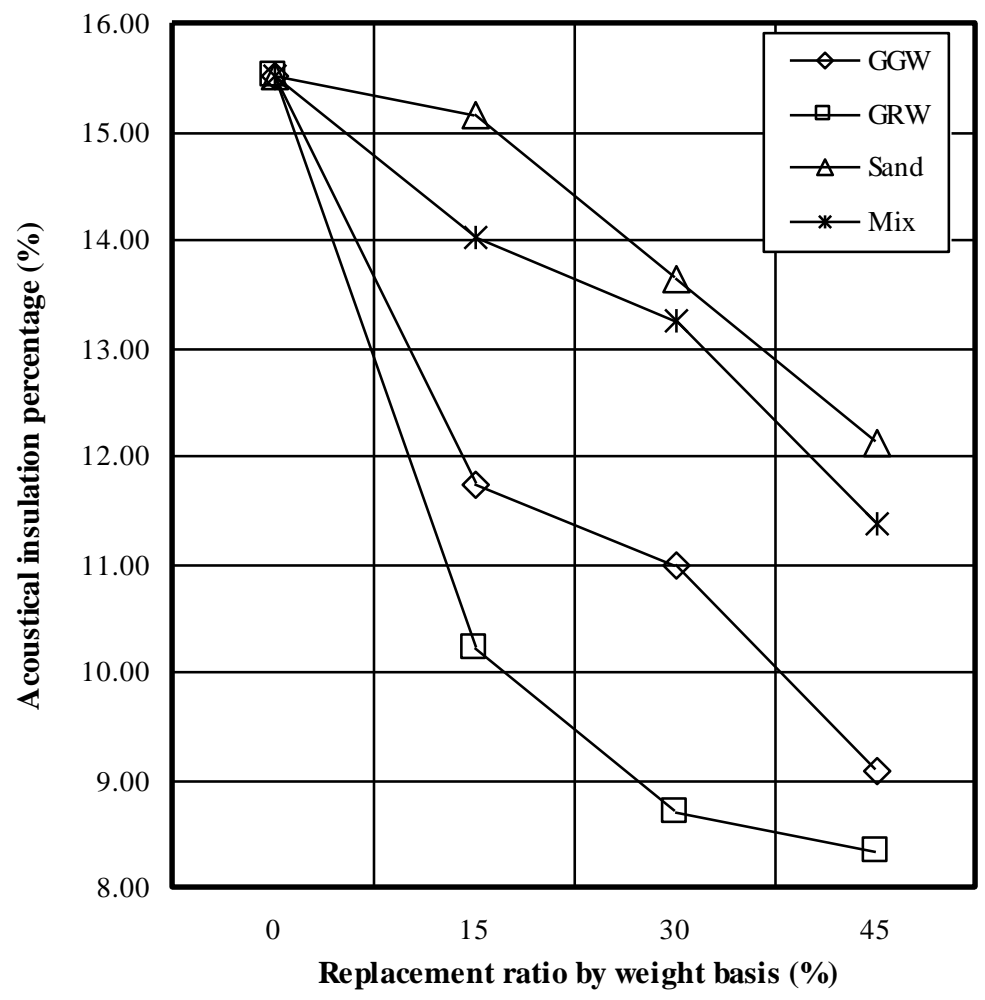

Fig.(4): Relationship between acoustical insulation percentage and the replacement ratios by weight basis for the four tested materials. 
The data indicated that the CSS mixture (contains sand) had the higher values of acoustical insulation percentage than the others mixtures except CS mixture (control), the values of acoustical insulation percentage of CSS mixture were $15.15,13.64$, and $12.12 \%$ at replacement ratios of 15 , 30 , and $45 \%$ respectively. The CSM mixture had nearest values to the CSS mixture. From the previous the sand is better in acoustical insulation percentage \%. The data showed that the CSG mixture (contain GGW) better than CSR mixture (contain GRW), at replacement ratio of $45 \%$, the acoustical insulation values of CSG mixture and CSR mixture were nearest each other.

Fig. (5) Illustrates that the relationship between water absorption percentage $(\%)$ and time $(\mathrm{min})$ at different replacement ratios of $0,15,30$ and $45 \%$ by weight basis for CSG, CSR, CSM, and CSS mixtures respectively as shown in figure (5). The obtained data indicated that generally the water absorption percentage (\%) increases with increasing time at any replacement ratio for CS, CSR, CSG, CSM and CSS mixtures respectively, the maximum value of water absorption percentage (\%) was $111.30 \%$ for CS (control) mixture after $120 \mathrm{~min}$ at replacement of $0 \%$. The minimum value of water absorption percentage (\%) was $48.78 \%$ for CSG mixture after $30 \mathrm{~min}$ at $45 \%$ replacement ratio. The obtained data showed that generally, the water absorption percentage $(\%)$ decreases with increasing of replacement ratio (\%) 45, 30, 15 and $0 \%$ respectively for CSS, CSM, CSG and CSR respectively. The lower values of water absorption percentage (\%) were at replacement ratio of $45 \%$ for CSG, CSS and CSM mixtures respectively than the other replacement ratio $\%$. The lower values of water absorption percentage $(\%)$ were at replacement ratio of $30 \%$ for CSS and CSM respectively than the other mixtures. From the previous results, at replacement ratio of $15 \%$ the CSS mixture (contains sand) better than the other mixtures; at replacement ratio of 30 $\%$ the CSS mixture (contains sand) better than the other mixtures, at replacement ratio of $45 \%$ the CSG mixture (GGW) better than the other mixtures. 


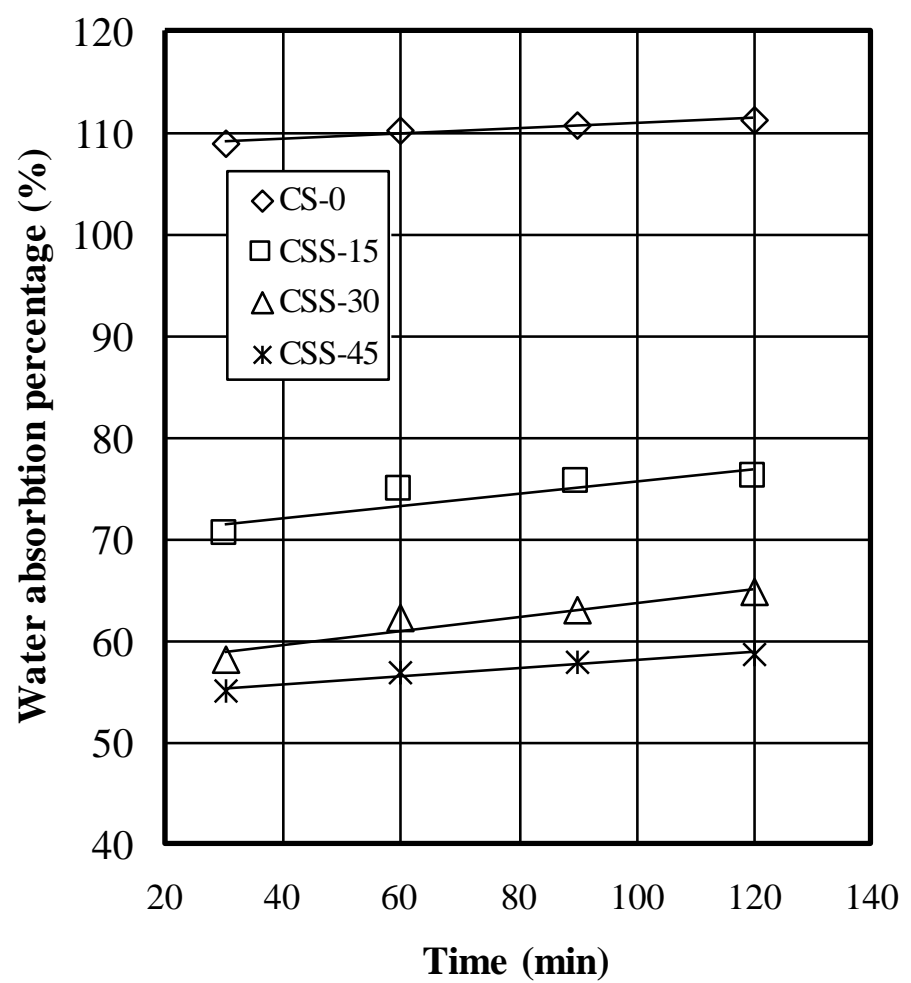

Fig.(5): Relationship between water absorption percentage and the time for the four tested materials.

\section{CONCOLOUSION}

The four used materials at the three ratios of each have in general better characteristics than the control straw brick. The replacement of sand gives better characteristics of water absorption, thermal conductivity and acoustical insulation while a mix of rubber and glass give the higher compressive stress. Generally the mixture replacement of rubber and sand was better in tests characteristics than each of them.

\section{REFERENCES}

Alaa El-Dine, M.N.; S.A. El-Shimi; M.H. Mahmoud and A.M. Abdel Aziz, (1983). Biogas for Egyptian villages (Energy - feltilizer forage) Soil and water research institute, Agri. Research Center, :257 (in Arabic). 
Corinaldesi, V.;G. Gnappi; G. Moriconi and A. Montenero, (2005). Reuse of ground waste glass as aggregate for mortars, Waste Manage, 25 (5): 197-201.

FAO (Food and Agriculture Organization of the United Nation) (2005). Quarterly bulletin of statistics, New York. (c.f. Moussa,2008).

Hermansson, L.A.,(1993). Cement-Bonded straw slabs, Feasibility study, Building Issues, 5(2): Lund University, Lund, Sweden. (c.f. Mansour et al.,2007).

Kazragis, A.,(2005). Minimization of atmosphere pollution by utilizing cellulose waste, Journal of Environmental Engineering and Landscape Management, 13(2): 81-90.

Mansour, A.; J. Srebric; and B.J.Burley,(2007). Development of strawcement composite sustainable building material for low-cost housing in Egypt, Journal of Applied Sciences Research, 3(11): 1571-1580.

Moussa, I.A.,(2008). Effect of some adhesive matter on agricultural wastes as building materials, MSc., Thesis, Ag. Eng. Dept., Faculty of Agriculture, Al-Azhar University.:4,20,23.

Noakes, G.R.; A.M. Oxon and F. Inst, (1953). Text-Book of heat, Macmilan and Co., Liwnrled, London, : 337-338.

Shayan, A., (2004).Value-added utilization of waste glass in concrete, Cem. Concr. Res., 34 (1):81-90.

Staniforth, A., (1979). Cereal straw, Clarendon Press., Oxford. (c.f. Moussa,2008)

Sukontasukkul, P., (2009). Use of crumb rubber to improve thermal and sound properties of pre-cast concrete panel, Construction and Building Materials, 23(2): 1048-1092.

Suliman, A.E. and A.M. El-Zahaby, (1998). Utilization of some field crops residues, 1st international conference on Rationalizate of Energy in Agriculture Ag. Mech. Dep., Faculty of Agriculture, Mansoura Univ. 17-18 March, 1998 : 173-187. 
Turgut, P., (2008). Properties of masonry blocks produced with waste limestone sawdust and glass powder, Construction and Building Materials, 22(7):1422-1427.

Yang, S.H.;D. Kim; Y. Lee;H. Kim; J. Jeon and C. Kang, (2004). Possibility of using waste tire composites reinforced with rice straw as construction materials, Bioresource Technology, 95(1): 61-65.

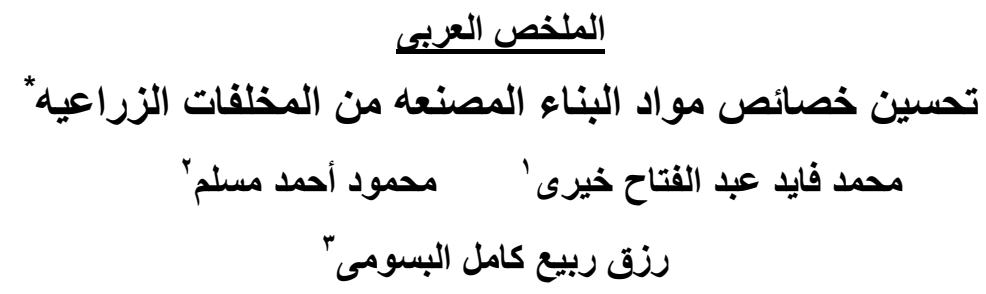

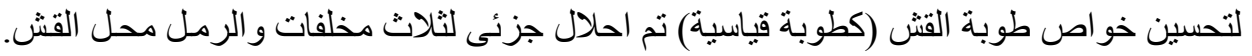

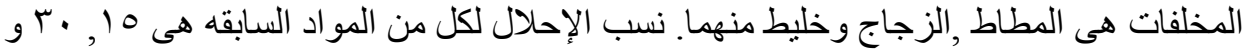
• ؛ \% على اساس الوزن. بعد عمل الإحلالات فإن الطوب الناتج تم إختباره للصفات الطات التالية:

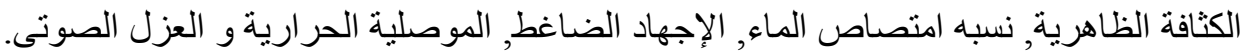

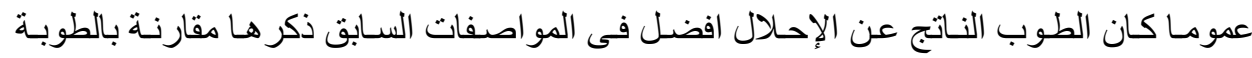

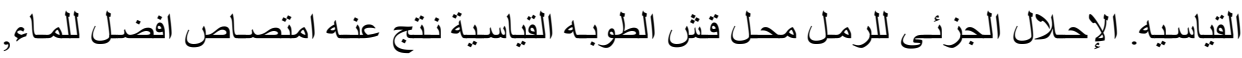

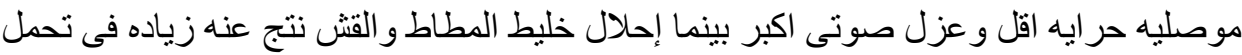

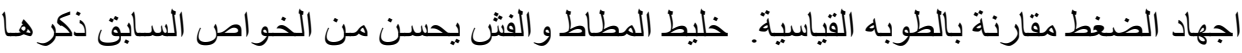

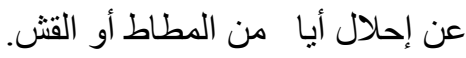

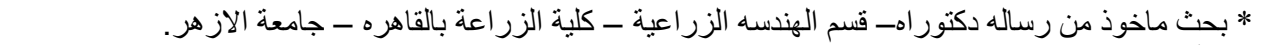

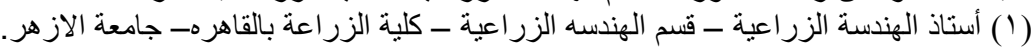

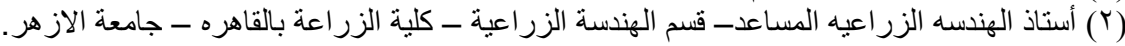

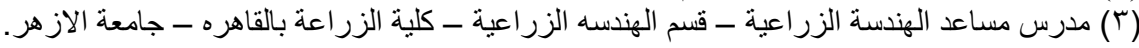

